\title{
Effects of Plasma Focus on Seed Germination and Seedling Growth of 14 Thai Rice Varieties
}

\author{
Vichai PURIPUNYAVANICH ${ }^{1, *}$, Arlee TAMMAN ${ }^{2}$, Piyanuch ORPONG ${ }^{1}$, \\ Roppon PICHA ${ }^{1}$, Mayuree LIMTIYAYOTHIN ${ }^{1}$, Pasit WONGHABUT ${ }^{2}$, \\ Wutthichok SANGWANG ${ }^{2}$, Kewalee NILGUMHANG ${ }^{2}$ and \\ Jiraporn PROMPING ${ }^{2}$
}

\author{
${ }^{1}$ Research and Development Division Thailand Institute of Nuclear Technology, \\ Nakhon Nayok 26120, Thailand \\ ${ }^{2}$ Center of Advanced Nuclear Technology, Thailand Institute of Nuclear Technology, \\ Nakhon Nayok 26120, Thailand
}

('Corresponding author's e-mail: vichaip@tint.or.th)

Received: 19 August 2020, Revised: 28 December 2020, Accepted: 5 January 2021

\begin{abstract}
Thailand Plasma Focus 2 (TPF-2) is operated at $2.16 \mathrm{~kJ}$ of storage energy with argon as a filled gas and can emit sharp $\mathrm{x}$-ray pulses to plant cells in nanosecond $\left(10^{-9} \mathrm{~s}\right)$ duration. The effects of plasma focus x-ray on seed germination and seedling growth of 14 Thai rice varieties treated under 10 conditions; 0 (control), 2, 4, 6, 8, 10, 12, 14, 16, and 18 plasma focus shots, were investigated. The results show that the germination rates and growth reduction rates were significantly different among the rice varieties. The germination rate of 10 varieties (Jek Chuey, KDML105, LPT123, PTT1, RD41, RD47, RD49, RD67, RD79, and SPR2) decreased when treated with a high number of plasma focus shots. $\mathrm{LD}_{50}$ and $\mathrm{GR}_{50}$ values were calculated, except for KTH17, RD1, RD7, and RD31 whose germination only slightly decreased, or remained constant, even after they were treated by 18 plasma focus shots.
\end{abstract}

Keywords: Plasma focus, Rice, Seed germination, Seedling growth

\section{Introduction}

Plasma focus is a pulsed operating device that mainly consists of a power source and electrodes. The power source uses a capacitor to store electrical energy, which is discharged through the RL load that is designed by the Lee code. The electrodes consist of an anode and cathode that are installed inside the vacuum chamber. The electrical energy from the power source generates plasma at the lower site of both electrodes. A high magnetic field generated by the current of the anode accelerates the plasma to the top of the electrodes and generates high density and high temperature plasma called the plasma pinch. X-rays and other species of high energy particle are generated [1-4]. The Lee code is used as a tool to design the plasma focus device and to calculate the plasma parameters such as plasma duration, plasma temperature, discharge voltage, discharge current, and x-ray production rate [5]. Thailand Plasma Focus 2 (TPF-2), a small plasma focus device, is designed for $3.3 \mathrm{~kJ}$ of maximum storage energy and $153 \mathrm{nH}$ of inductance load [4]. Pinch duration and pinch temperature are $11.34 \mathrm{~ns}$ and $332 \mathrm{eV}$, respectively, as calculated by the Lee code [4].

Mutation breeding is used in many fields and has provided benefits in plant breeding since the demonstration of mutagenesis in maize and barley using x-rays and gamma rays. Using plasma focus is different from normal x-ray irradiation because plasma focus emits a sharp x-ray injection to plant cells in 
http://wjst.wu.ac.th

nanosecond $\left(10^{-9} \mathrm{~s}\right)$ duration. The $\mathrm{x}$-ray energy for the small plasma focuses up to $600 \mathrm{keV}$ and an $\mathrm{x}$-ray dose of higher than 50 mGy per shot [2]. The study of the effects of plasma are widely known by use of non-thermal plasma for different applications such as surface treatment, antimicrobial treatments, and plant response research. The use of non-thermal plasma has potential to reduce microbial activity and enhance seed germination and seedling growth in plants [6-9]. Studies of plant response by using plasma focus are not widely known. Therefore, the study of effects of plasma focus on rice seeds will help to understand the response of plants to plasma focus radiation and the useful application of plasma focus technique on plant mutation breeding. This study aimed to investigate the sensitivity and the response of rice induced by plasma focus. The rice seeds were irradiated with plasma focus shots. The lethal dose (LD) and growth reduction (GR) were determined. $\mathrm{LD}_{50}$ is the dose that causes seeds to die by $50 \%$ as compared to the control. GR is the dose that reduces the growth rate by $50 \%$ as compared to the control.

\section{Materials and methods}

\section{Seed treatments}

14 varieties of rice seeds: Jek Chuey, Kao Dok Mali 105 (KDML105), Khao Tah Haeng 17 (KTH 17), Leuang Pratew 123 (LPT123), Pathum Thani 1 (PTT1), RD1, RD7, RD31, RD41, RD47, RD49, RD67, RD79, and Suphan Buri 2 (SPR2), were obtained from Chachoengsao Rice Research Center. The rice seeds were packed in polyethylene (PE) zipper bags, with 10 seeds of the same variety in each bag. Each rice variety sample was irradiated for 3 replications. After irradiation, all seeds were sown on top of wet tissue papers on a plastic tray and kept in a dark condition for 10 days. Germination percentage and growth reduction percentage were recorded. $\mathrm{LD}_{50}$ and $\mathrm{GR}_{50}$ values were estimated from the graphs between the number of plasma focus shots and germination percentage and growth rate, respectively, to determine the effects of plasma focus on rice variety response.

\section{Plasma focus irradiation}

The 1-year-old rice seeds were treated with the plasma focus in 10 treatment conditions: $0,2,4,6$, $8,10,12,14,16$, and 18 shots. TPF-2 device was prepared by a vacuum pumping process to clean out any remaining gas. The base pressure of the system was about $5 \times 10^{-3}$ Torr. After that, the operating gas was injected into the chamber at the operating pressure, 1 - 10 Torr. The capacitor was charged to the operating voltage, $12 \mathrm{kV}$, which stored electrical energy of up to $2.16 \mathrm{~kJ}$. High-voltage and high-current spark gap was used as a switch to transfer the stored electrical energy to the device electrodes for plasma generation inside the vacuum chamber. The plasma was generated and accelerated up to the top of the electrodes and ended up in a plasma pinch. The pinch produced x-rays, high density visible light, electron beams, and ion beams.

\section{Statistical analysis}

The data were analyzed using analysis of variance, after which means were compared using the least significant difference (LSD). The analyses were facilitated by the R program [1].

\section{Results and discussion}

Effects of plasma focus on seed germination

The effects of plasma focus irradiation on germination were assessed by counting seed germination of 14 Thai rice varieties at 10 days after sowing and calculating the percentage of germination compared with control. The effects of plasma focus on 14 Thai rice varieties are shown in Table 1 and Figure 1. Jek Chuey, KDML105, LPT123, PTT1, RD41, RD47, RD49, RD67, RD79, and SPR2 were significantly decreased when shot of plasma focus increased. This result agrees with Yamaguchi et al. [10], who studied the effects of ion beam and gamma irradiation on rice; the results showed that the hulled dry seed treated with ion beam and gamma ray had survival rates which decreased with increased radiation dose. KTH17, RD1, RD7, and RD31 germination rates were slightly decreased when the number of plasma focus shots increased. There was no statistically significant change in germination at different doses for 
KTH17 and RD1. For the effects of plasma focus on rice variety response determination, $\mathrm{LD}_{50}$ values were used as an indicator of toxicity and calculated by seed germination percentage. The highest radiation doses of Jek Chuey, KDML105, LPT123, PTT1, RD41, RD47, RD49, RD67, RD79, and SPR2 had percentages of germination of less than $50 \%$, so that $\mathrm{LD}_{50}$ could be calculated. The $\mathrm{LD}_{50}$ values were approximately $17,8.5,17,13.5,13.5,8,15,13,14$, and 11 shots, respectively. This group is, therefore, considered to be sensitive to plasma irradiation. However, for KTH17, RD1, RD7, and RD31, the LD $_{50}$ could not be determined, because at the highest plasma focus shot, the germination percentage was higher than $50 \%$. These varieties can be considered resistant to plasma irradiation. The results were in accordance with Sasikala and Kalaiyarasi [11], who studied sensitivity of rice varieties to gamma irradiation in 6 rice varieties; the survival percentages were decreased when the dosages of radiation increased, but the responses of all 6 rice varieties had different survival percentages. The different results may be due to different rice species having different radiation responses and different radiation types. At low numbers of plasma focus shot, seed germination was not significantly different from control (Table 1, Figure 1). The result is similar to the experiment of $\mathrm{Xu}$ et al. [12], who studied the effects of heavy ion irradiation on rice seeds and found that low-energy ions had no significant influence on germination, survival, or seedling height, and medium-energy ions had a significant influence on germination.

From the experiment, at low doses, the plasma can stimulate seed germination of some rice varieties. The germination rates of Jek Chuey, KDML105, KTH17, PTT1, RD1, RD41, and RD49 were slightly increased at low numbers of plasma focus shot, but the changes were not statistically significant. Previous studies have reported that low dose radiation exposure can enhance the germination rates of bottle gourd, pumpkin, red sandalwood, tomato, rice, cucumber, and okra [13-17]. The enhancement of germination rate may be caused by the stimulation of cell division and pathways that affect the synthesis of nucleic acids, the activation of RNA, or protein synthesis [18,19]. Furthermore, some rice varieties have a seed dormancy period, which is a survival mechanism to protect seeds from unfavorable environmental conditions. Plasma focus exposure may break this dormancy phase and promote phytohormone synthesis, such as gibberellic acid in seeds, that activate the signaling pathway and enzymes which relate to the degradation of food reserves and, thus, improve the germination rate [20,21]. 

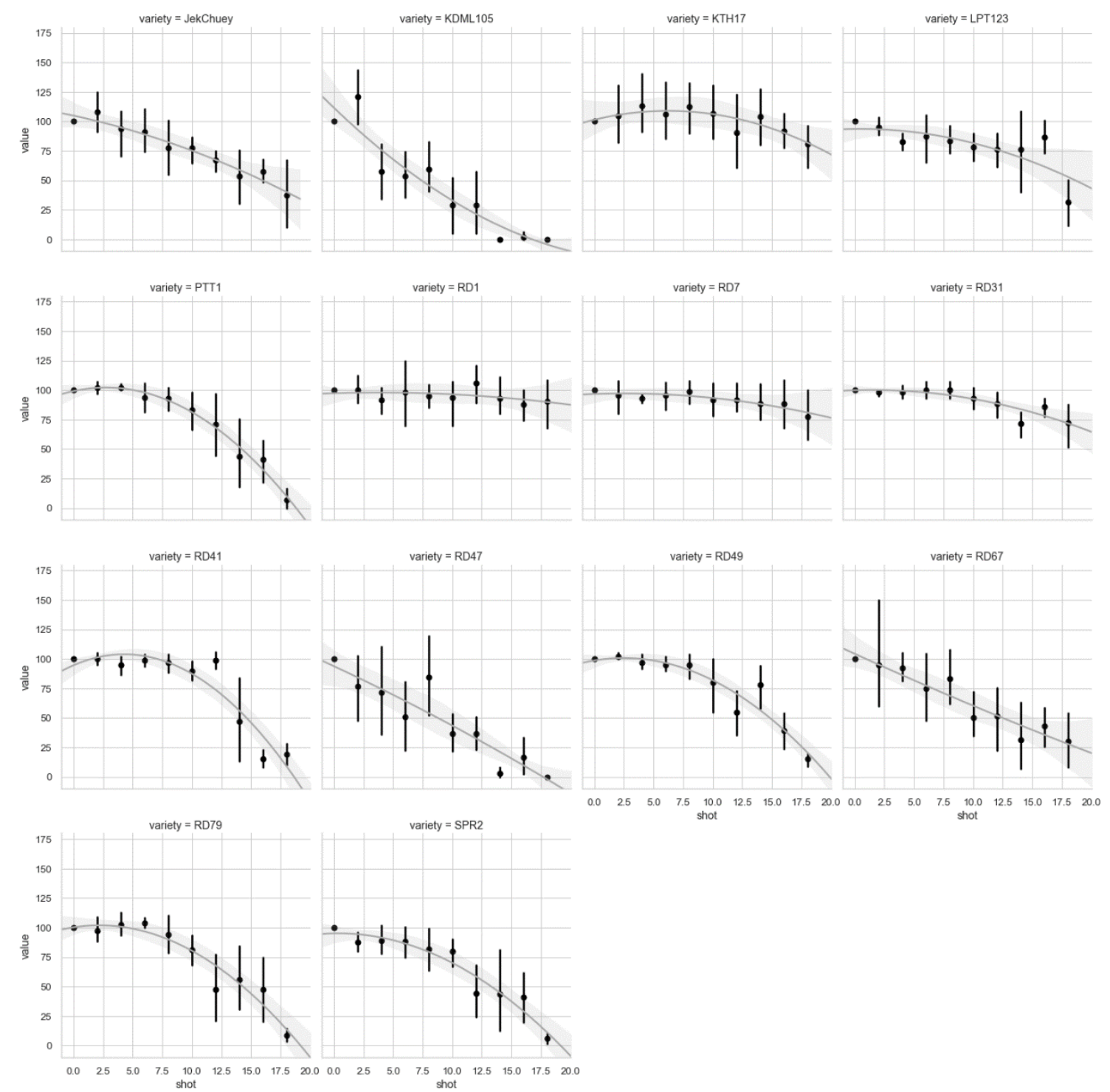

Figure 1 Relative germination of 14 Thai rice varieties at 10 days after plasma focus irradiation. 
Plasma Focus on Seed Germination and Seedling Growth of Thai Rice Vichai PURIPUNYAVANICH et al. http://wjst.wu.ac.th

Table 1 Relative germination of 14 Thai rice varieties at 10 days after plasma focus irradiation.

\begin{tabular}{|c|c|c|c|c|c|c|c|c|c|c|c|c|c|c|}
\hline \multirow{2}{*}{$\begin{array}{c}\text { Dose } \\
\text { (shot) }\end{array}$} & \multicolumn{14}{|c|}{ Germination rate } \\
\hline & $\begin{array}{c}\text { Jek } \\
\text { Chuey }\end{array}$ & KDML105 & КTH17 & LPT123 & PTT 1 & RD1 & RD7 & RD31 & RD41 & RD47 & RD49 & RD67 & RD79 & SPR2 \\
\hline 2 & $106.60^{\mathrm{a}}$ & $112.40^{\mathrm{a}}$ & $101.9^{\mathrm{a}}$ & $94.54^{\mathrm{ab}}$ & $101.80^{\mathrm{a}}$ & $100.50^{\mathrm{a}}$ & $95.38^{\mathrm{ab}}$ & $98.33^{\mathrm{a}}$ & $100.10^{\mathrm{a}}$ & $77.78^{\mathrm{ab}}$ & $101.80^{\mathrm{a}}$ & $87.14^{\mathrm{a}}$ & $96.67^{\mathrm{a}}$ & $88.24^{\mathrm{ab}}$ \\
\hline 4 & $94.92^{\mathrm{ab}}$ & $55.64^{\mathrm{b}}$ & $109.80^{\mathrm{a}}$ & $82.16^{\mathrm{bc}}$ & $101.80^{\mathrm{a}}$ & $91.37^{\mathrm{a}}$ & $92.86^{\mathrm{ab}}$ & $98.43^{\mathrm{a}}$ & $94.91^{\mathrm{a}}$ & $62.96^{\mathrm{bc}}$ & $96.67^{\mathrm{a}}$ & $89.64^{\mathrm{a}}$ & $102.00^{\mathrm{a}}$ & $88.24^{\mathrm{ab}}$ \\
\hline 6 & $90.26^{\mathrm{ab}}$ & $57.52^{\mathrm{b}}$ & $104.10^{\mathrm{a}}$ & $85.77^{\mathrm{abc}}$ & $93.16^{\mathrm{a}}$ & $98.33^{\mathrm{a}}$ & $95.09^{\mathrm{ab}}$ & $100.30^{\mathrm{a}}$ & $98.25^{\mathrm{a}}$ & $46.3^{c}$ & $95.00^{\mathrm{a}}$ & $74.81^{\mathrm{ab}}$ & $103.60^{\mathrm{a}}$ & $88.24^{\mathrm{ab}}$ \\
\hline 8 & $76.97^{\mathrm{bc}}$ & $54.96^{\mathrm{b}}$ & $110.30^{\mathrm{a}}$ & $82.26^{\mathrm{bc}}$ & $93.07^{\mathrm{a}}$ & $94.95^{\mathrm{a}}$ & $98.63^{\mathrm{a}}$ & $100.30^{\mathrm{a}}$ & $96.67^{\mathrm{a}}$ & $77.78^{\mathrm{ab}}$ & $94.82^{\mathrm{a}}$ & $78.49^{\mathrm{ab}}$ & $92.96^{\mathrm{ab}}$ & $82.36^{\mathrm{b}}$ \\
\hline 10 & $77.97^{\mathrm{bc}}$ & $32.69^{c}$ & $103.20^{\mathrm{a}}$ & $76.80^{\mathrm{c}}$ & $82.98^{\mathrm{ab}}$ & $93.70^{\mathrm{a}}$ & $91.29^{\mathrm{ab}}$ & $92.86^{\mathrm{a}}$ & $89.74^{\mathrm{a}}$ & $37.97^{\mathrm{cd}}$ & $79.47^{\mathrm{b}}$ & $48.32^{\mathrm{c}}$ & $80.48^{\mathrm{b}}$ & $80.4^{\mathrm{b}}$ \\
\hline 12 & $67.71^{\mathrm{cd}}$ & $32.14^{\mathrm{c}}$ & $87.72^{\mathrm{a}}$ & $74.85^{\mathrm{c}}$ & $70.97^{\mathrm{b}}$ & $105.60^{\mathrm{a}}$ & $91.7^{\mathrm{ab}}$ & $88.16^{\mathrm{a}}$ & $98.42^{\mathrm{a}}$ & $37.04^{\mathrm{cd}}$ & $54.12^{\mathrm{c}}$ & $55 b^{c}$ & $47.26^{\mathrm{c}}$ & $43.14^{\mathrm{c}}$ \\
\hline 16 & $57.97^{\text {cde }}$ & $2.22^{\mathrm{d}}$ & $90.76^{\mathrm{a}}$ & $85.77^{\mathrm{abc}}$ & $40.96^{\mathrm{c}}$ & $87.57^{\mathrm{a}}$ & $88.66^{\mathrm{ab}}$ & $86.12^{\mathrm{ab}}$ & $15.44^{\mathrm{c}}$ & $12.04^{\mathrm{de}}$ & $39.04^{\mathrm{d}}$ & $44.45^{\mathrm{c}}$ & $47.38^{\mathrm{c}}$ & $39.21^{\mathrm{c}}$ \\
\hline 18 & $38.28^{\mathrm{e}}$ & $0.00^{\mathrm{d}}$ & $79.30^{\mathrm{a}}$ & $30.31^{\mathrm{d}}$ & $7.02^{\mathrm{d}}$ & $90.42^{\mathrm{a}}$ & $77.22^{\mathrm{b}}$ & $72.35^{\mathrm{b}}$ & $19.12^{\mathrm{c}}$ & $0.00^{\mathrm{e}}$ & $15.26^{\mathrm{e}}$ & $37.31^{\mathrm{c}}$ & $9.07^{\mathrm{d}}$ & $5.88^{d}$ \\
\hline F-test & $* *$ & $* *$ & $\mathrm{~ns}$ & $* *$ & $* *$ & $\mathrm{~ns}$ & $*$ & $*$ & $* *$ & $* *$ & $* *$ & $* *$ & $* *$ & $* *$ \\
\hline $\operatorname{LSD}_{0.05}$ & 21.41 & 16.94 & 31.62 & 16.23 & 19.02 & 30.74 & 21.29 & 15.24 & 11.27 & 29.76 & 12.63 & 25.22 & 14.42 & 15.84 \\
\hline
\end{tabular}

*Significant.

**Highly significant.

ns Non-significant difference.

${ }^{1 /}$ Different letters in the same column mean that the data are statistically different from the least significant difference $(\mathrm{p}<0.05)$. 
http://wjst.wu.ac.th

\section{Effects of plasma focus on growth rate}

The effects of plasma focus irradiation on growth were assessed by measuring the shoot and root lengths at 10 days after irradiation and calculating the growth rate compared with control. From our statistical analysis, the radiation effect can be grouped into 2 main response types: those varieties whose growth significantly decreased, and those whose growth reduction was not significant. The $1^{\text {st }}$ group consisted of Jek Chuey, KDML105, LPT123, PTT1, RD41, RD47, RD49, RD67, RD79, and SPR2, of which GR $_{50}$ were 13, 9, 17, 13.5, 14.5, 9, 15, 13, 11, and 10.5 shots, respectively (Tables 2 - 3, Figure 2). In this group, the growth percentage dropped by at least $50 \%$ at the highest number of plasma shots. This conforms to the results of Yasmine et al. [22], who studied the effects of chronic gamma irradiation on rice. Chronic gamma irradiation produced inhibitory effects on rice plant height. Sasikala and Kalaiyarasi [11] showed that seedling height decreased with increase of gamma irradiation dose. The $2^{\text {nd }}$ group, which showed high resistance to plasma shots, consisted of KTH17, $\mathrm{RD} 1, \mathrm{RD} 7$, and RD31. In this group, the growth percentage was still above $50 \%$ at the highest number of plasma shots; thus, the $\mathrm{GR}_{50}$ could not be determined (Table 2, Figure 2).

The results showed, that at lower doses, the plasma could induce plant growth for most varieties, except for RD31, RD47, RD67, and SPR2. Rezk et al. [23] studied the effect of x-ray irradiation on seed germination and biochemical analysis of okra and reported that low doses of up to 5 Gy caused a stimulation effect in morphological growth and the amount of antioxidants. The result agrees with previous studies which showed positive effects of a low dose of radiation exposure, which could be used to enhance growth in plants such as tomato, pepper, Arabidopsis, and mung bean [24-26]. Ling et al. [27] reported that seed reserve food utilization and the content of sugar and protein in seedlings increased after plasma exposure. Other studies have also reported that plasma treatment generated reactive oxygen and nitrogen species (RONS) such as $\mathrm{NO}_{2}^{-}$, $\mathrm{NO}_{3}^{-}$, and $\mathrm{H}_{2} \mathrm{O}_{2}$ which resulted in growth stimulation [25,28]. The concentration of plant hormones, auxin and cytokinin, was increased in seedlings exposed to low-thermal plasma [29]. Therefore, the effect of plasma focus on plant growth may be related to nutrient levels, growth hormones, and the activation of gene expression. 
http://wjst.wu.ac.th

Table 2 Growth percentages of seedlings of 7 Thai rice varieties ( $1^{\text {st }}$ group) at 10 days after plasma focus irradiation.

\begin{tabular}{|c|c|c|c|c|c|c|c|c|c|c|c|c|c|c|}
\hline \multirow{3}{*}{$\begin{array}{c}\text { Dose } \\
\text { (shot) }\end{array}$} & \multicolumn{14}{|c|}{ Growth percentage of seedlings } \\
\hline & \multicolumn{2}{|c|}{ Jek Chuey } & \multicolumn{2}{|c|}{ KDML105 } & \multicolumn{2}{|c|}{ KTH17 } & \multicolumn{2}{|c|}{ LPT123 } & \multicolumn{2}{|c|}{ PTT 1} & \multicolumn{2}{|c|}{ RD1 } & \multicolumn{2}{|c|}{ RD7 } \\
\hline & Shoot & Root & Shoot & Root & Shoot & Root & Shoot & Root & Shoot & Root & Shoot & Root & Shoot & Root \\
\hline 0 & $100.00^{\mathrm{a}}$ & $100.00^{\mathrm{ab} 1 /}$ & $100^{\mathrm{a}}$ & $100^{\mathrm{b}}$ & 100 & 100 & $100.00^{\mathrm{a}}$ & $100.00^{\mathrm{a}}$ & $100.00^{\mathrm{ab}}$ & $100.00^{\mathrm{ab}}$ & 100 & 100 & 100 & $100.00^{\mathrm{ab}}$ \\
\hline 2 & $107.00^{\mathrm{a}}$ & $100.40^{\mathrm{ab}}$ & $117.1^{\mathrm{a}}$ & $135.8^{\mathrm{a}}$ & 116.2 & 120.8 & $100.80^{\mathrm{a}}$ & $89.84^{\mathrm{ab}}$ & $109.50^{\mathrm{a}}$ & $99.98^{\mathrm{ab}}$ & 111.1 & 102.2 & 106.8 & $100.00^{\mathrm{ab}}$ \\
\hline 4 & $87.42^{\mathrm{ab}}$ & $86.60^{\mathrm{abc}}$ & $53.79^{\mathrm{b}}$ & $54.45^{\text {cde }}$ & 111.9 & 115.9 & $89.15^{\mathrm{ab}}$ & $87.46^{\mathrm{ab}}$ & $106.00^{\mathrm{ab}}$ & $102.20^{\mathrm{ab}}$ & 81.16 & 88.55 & 109.3 & $101.80^{\mathrm{ab}}$ \\
\hline 6 & $80.38^{\mathrm{abc}}$ & $123.40^{\mathrm{a}}$ & $63.96^{\mathrm{b}}$ & $72.97^{\mathrm{c}}$ & 106.7 & 109.4 & $85.70^{\mathrm{abc}}$ & $77.80^{\mathrm{bc}}$ & $95.60^{\mathrm{ab}}$ & $112.10^{\mathrm{a}}$ & 119.7 & 109.8 & 102.8 & $89.81^{\mathrm{ab}}$ \\
\hline 8 & $87.79^{\mathrm{ab}}$ & $89.10^{\mathrm{abc}}$ & $54.82^{\mathrm{b}}$ & $68.05^{\mathrm{cd}}$ & 116.1 & 125.8 & $97.14^{\mathrm{ab}}$ & $82.46^{\mathrm{ab}}$ & $96.60^{\mathrm{ab}}$ & $93.49^{\mathrm{ab}}$ & 103.4 & 120.2 & 113.5 & $99.22^{\mathrm{ab}}$ \\
\hline 10 & $49.36^{\mathrm{cd}}$ & $56.35^{\mathrm{bcd}}$ & $44.37^{\mathrm{b}}$ & $46 \mathrm{~d}^{\mathrm{e}}$ & 104.3 & 127.7 & $76.55^{\text {abc }}$ & $75.85^{\text {bc }}$ & $90.97^{\mathrm{bc}}$ & $98.08^{\mathrm{ab}}$ & 100 & 121 & 109.7 & $112.60^{\mathrm{a}}$ \\
\hline 12 & $55.73^{\text {bcd }}$ & $76.49^{\mathrm{abc}}$ & $36.6^{\mathrm{b}}$ & $41.9^{\mathrm{e}}$ & 85.34 & 89.7 & $73.04 b^{c}$ & $70.28^{\mathrm{bc}}$ & $75.9^{\mathrm{c}}$ & $83.34^{\mathrm{b}}$ & 114.4 & 127.2 & 106.9 & $94.40^{\mathrm{ab}}$ \\
\hline 14 & $8.35^{\mathrm{e}}$ & $22.93^{\mathrm{d}}$ & $0^{\mathrm{c}}$ & $0^{\mathrm{f}}$ & 107 & 113.9 & $64.33^{c}$ & $60.70^{\mathrm{c}}$ & $42.79^{\mathrm{d}}$ & $41.95^{\mathrm{c}}$ & 107.3 & 119.4 & 108.7 & $93.02^{\mathrm{ab}}$ \\
\hline 16 & $41.85^{\mathrm{d}} \mathrm{e}$ & $44.84^{\mathrm{cd}}$ & $1.89^{c}$ & $1.91^{\mathrm{f}}$ & 89.97 & 96.52 & $80.53^{\mathrm{abc}}$ & $77.35^{\mathrm{bc}}$ & $39.86^{\mathrm{d}}$ & $39.67^{\mathrm{c}}$ & 100.7 & 109 & 106.3 & $90.17^{\mathrm{ab}}$ \\
\hline 18 & $25.06^{\mathrm{de}}$ & $10.09^{\mathrm{d}}$ & $0^{\mathrm{c}}$ & $0^{\mathrm{f}}$ & 86.13 & 111.7 & $28.40^{\mathrm{d}}$ & $27.26^{\mathrm{d}}$ & $4.76^{\mathrm{e}}$ & $2.73^{d}$ & 94.82 & 79.2 & 82.5 & $73.48^{\mathrm{b}}$ \\
\hline F-test & $* *$ & $* *$ & $* *$ & $* *$ & $\mathrm{~ns}$ & $\mathrm{~ns}$ & $* *$ & $* *$ & $* *$ & $* *$ & $\mathrm{~ns}$ & $\mathrm{~ns}$ & ns & $*$ \\
\hline $\mathrm{LSD}_{0.05}$ & 37.4 & 47.62 & 29.22 & 25.63 & 39.65 & 50.93 & 24.74 & 19.76 & 18.41 & 19.29 & 45.37 & 57.81 & 51.27 & 33.28 \\
\hline
\end{tabular}

* Significant.

**Highly significant

ns Non-significant difference.

${ }^{1 /}$ Different letters in the same column mean that the data are statistically different from the least significant difference $(\mathrm{p}<0.05)$. 
http://wjst.wu.ac.th

Table 3 Growth percentages of seedlings of 7 Thai rice varieties ( $2^{\text {nd }}$ group) at 10 days after plasma focus irradiation.

\begin{tabular}{|c|c|c|c|c|c|c|c|c|c|c|c|c|c|c|}
\hline \multirow{3}{*}{$\begin{array}{c}\text { Dose } \\
\text { (shot) }\end{array}$} & \multicolumn{14}{|c|}{ Growth percentage of seedlings } \\
\hline & \multicolumn{2}{|c|}{ RD31 } & \multicolumn{2}{|c|}{ RD41 } & \multicolumn{2}{|c|}{ RD47 } & \multicolumn{2}{|c|}{ RD49 } & \multicolumn{2}{|c|}{ RD67 } & \multicolumn{2}{|c|}{ RD79 } & \multicolumn{2}{|c|}{ SPR2 } \\
\hline & Shoot & Root & Shoot & Root & Shoot & Root & Shoot & Root & Shoot & Root & Shoot & Root & Shoot & Root \\
\hline 0 & $100.00^{\mathrm{a}}$ & $100.00^{\mathrm{ab} 1 /}$ & $100.00^{\mathrm{a}}$ & $100.00^{\mathrm{ab}}$ & $100.00^{\mathrm{a}}$ & $100.00^{\mathrm{a}}$ & $100.00^{\mathrm{ab}}$ & $100.00^{\mathrm{a}}$ & $100.00^{\mathrm{a}}$ & $100.00^{\mathrm{ab}}$ & $100.00^{\mathrm{a}}$ & $100.00^{\mathrm{a}}$ & $100.00^{\mathrm{a}}$ & $100.00^{\mathrm{a}}$ \\
\hline 2 & $80.02^{\mathrm{ab}}$ & $94.31^{\mathrm{abcd}}$ & $108.60^{\mathrm{a}}$ & $103.90^{\mathrm{a}}$ & $65.22^{\mathrm{b}}$ & $70.66^{\mathrm{b}}$ & $108.30^{\mathrm{a}}$ & $102.40^{\mathrm{a}}$ & $99.18^{\mathrm{a}}$ & $125.20^{\mathrm{a}}$ & $102.40^{\mathrm{a}}$ & $95.32^{\mathrm{ab}}$ & $88.16^{\mathrm{a}}$ & $99.27^{\mathrm{a}}$ \\
\hline 4 & $82.84^{\mathrm{ab}}$ & $91.22^{\mathrm{bcd}}$ & $102.10^{\mathrm{a}}$ & $87.46^{\mathrm{b}}$ & $44.69^{\mathrm{bcd}}$ & $49.78^{\mathrm{bc}}$ & $99.86^{\mathrm{ab}}$ & $103.50^{\mathrm{a}}$ & $79.69^{\mathrm{ab}}$ & $98.33^{\mathrm{ab}}$ & $103.70^{\mathrm{a}}$ & $93.10^{\mathrm{ab}}$ & $124.70^{\mathrm{a}}$ & $113.00^{\mathrm{a}}$ \\
\hline 6 & $88.61^{\mathrm{ab}}$ & $113.80^{\mathrm{a}}$ & $97.68^{\mathrm{a}}$ & $94.65^{\mathrm{ab}}$ & $31.34^{\text {cde }}$ & $28.52^{\text {cde }}$ & $96.95^{\mathrm{ab}}$ & $93.00^{\mathrm{a}}$ & $58.10^{\mathrm{bc}}$ & $86.07^{\mathrm{abc}}$ & $106.80^{\mathrm{a}}$ & $99.02^{\mathrm{a}}$ & $92.56^{\mathrm{a}}$ & $101.00^{\mathrm{a}}$ \\
\hline 8 & $84.44^{\mathrm{ab}}$ & $112.60^{\mathrm{ab}}$ & $99.92^{\mathrm{a}}$ & $91.68^{\mathrm{ab}}$ & $58.60^{\mathrm{bc}}$ & $61.44^{\mathrm{d}}$ & $99.34^{\mathrm{ab}}$ & $92.66^{\mathrm{a}}$ & $61.14^{\mathrm{bc}}$ & $81.87^{\mathrm{abc}}$ & $98.52^{\mathrm{a}}$ & $93.16^{\mathrm{ab}}$ & $91.53^{\mathrm{a}}$ & $118.40^{\mathrm{a}}$ \\
\hline 10 & $73.51^{\mathrm{ab}}$ & $98.70^{\mathrm{abc}}$ & $88.57^{\mathrm{a}}$ & $87.75^{\mathrm{b}}$ & $38.82^{\mathrm{bcd}}$ & $33.51 \mathrm{c}^{\mathrm{d}}$ & $88.04^{\mathrm{ab}}$ & $89.06^{\mathrm{a}}$ & $37.15^{\mathrm{c}}$ & $60.24^{\mathrm{bc}}$ & $76.45^{\mathrm{b}}$ & $75.45^{\mathrm{b}}$ & $92.27^{\mathrm{a}}$ & $90.22^{\mathrm{a}}$ \\
\hline 12 & $77.71^{\mathrm{ab}}$ & $95.83^{\mathrm{abcd}}$ & $92.1^{\mathrm{a}}$ & $92.26^{\mathrm{ab}}$ & $26.07^{\mathrm{def}}$ & $24.57^{\mathrm{de}}$ & $55.33^{\mathrm{c}}$ & $51.91^{\mathrm{b}}$ & $58.84^{\mathrm{bc}}$ & $77.47^{\text {bc }}$ & $43.23^{\mathrm{c}}$ & $48.50^{\mathrm{c}}$ & $40.87^{\mathrm{b}}$ & $49.61^{b}$ \\
\hline 14 & $60.31^{\mathrm{b}}$ & $76.42^{\mathrm{cd}}$ & $52.43^{\mathrm{b}}$ & $55.56^{\mathrm{c}}$ & $3.07^{\mathrm{ef}}$ & $0.88^{\mathrm{f}}$ & $84.47^{\mathrm{b}}$ & $85.25^{\mathrm{a}}$ & $36.22^{\mathrm{c}}$ & $42.20^{\mathrm{c}}$ & $50.93^{\mathrm{c}}$ & $52.77^{\mathrm{c}}$ & $39.26^{\mathrm{b}}$ & $43.55^{\mathrm{b}}$ \\
\hline 16 & $68.67^{\mathrm{ab}}$ & $92.53^{\mathrm{abcd}}$ & $10.22^{\mathrm{c}}$ & $15.30^{\mathrm{d}}$ & $9.54^{\mathrm{ef}}$ & $11.07^{\mathrm{ef}}$ & $37.75^{\mathrm{c}}$ & $39.80^{\mathrm{b}}$ & $35.53^{\mathrm{c}}$ & $60.68 b^{c}$ & $38.08^{\mathrm{c}}$ & $45.06^{\mathrm{c}}$ & $40.46^{\mathrm{b}}$ & $45.34^{b}$ \\
\hline 18 & $64.57^{\mathrm{b}}$ & $74.22^{\mathrm{d}}$ & $11.93^{\mathrm{c}}$ & $14.35^{\mathrm{d}}$ & $0.00^{\mathrm{f}}$ & $0.00^{\mathrm{f}}$ & $12.5^{\mathrm{d}}$ & $11.51^{\mathrm{c}}$ & $37.65^{\mathrm{c}}$ & $45.09^{\mathrm{c}}$ & $6.43^{d}$ & $6.51^{\mathrm{d}}$ & $2.167^{\mathrm{b}}$ & $3.433^{\mathrm{c}}$ \\
\hline F-test & $*$ & * & $* *$ & $* *$ & $* *$ & $* *$ & $* *$ & $* *$ & $* *$ & * & $* *$ & $* *$ & $* *$ & $* *$ \\
\hline $\mathrm{LSD}_{0.05}$ & 32.66 & 22.36 & 20.9 & 13.35 & 28.97 & 21.93 & 21.34 & 22.69 & 27.62 & 45.64 & 18.64 & 22.65 & 46.62 & 32.43 \\
\hline
\end{tabular}

*Significant.

**Highly significant.

${ }^{1 /}$ Different letters in the same column mean that the data are statistically different from the least significant difference $(\mathrm{p}<0.05)$. 

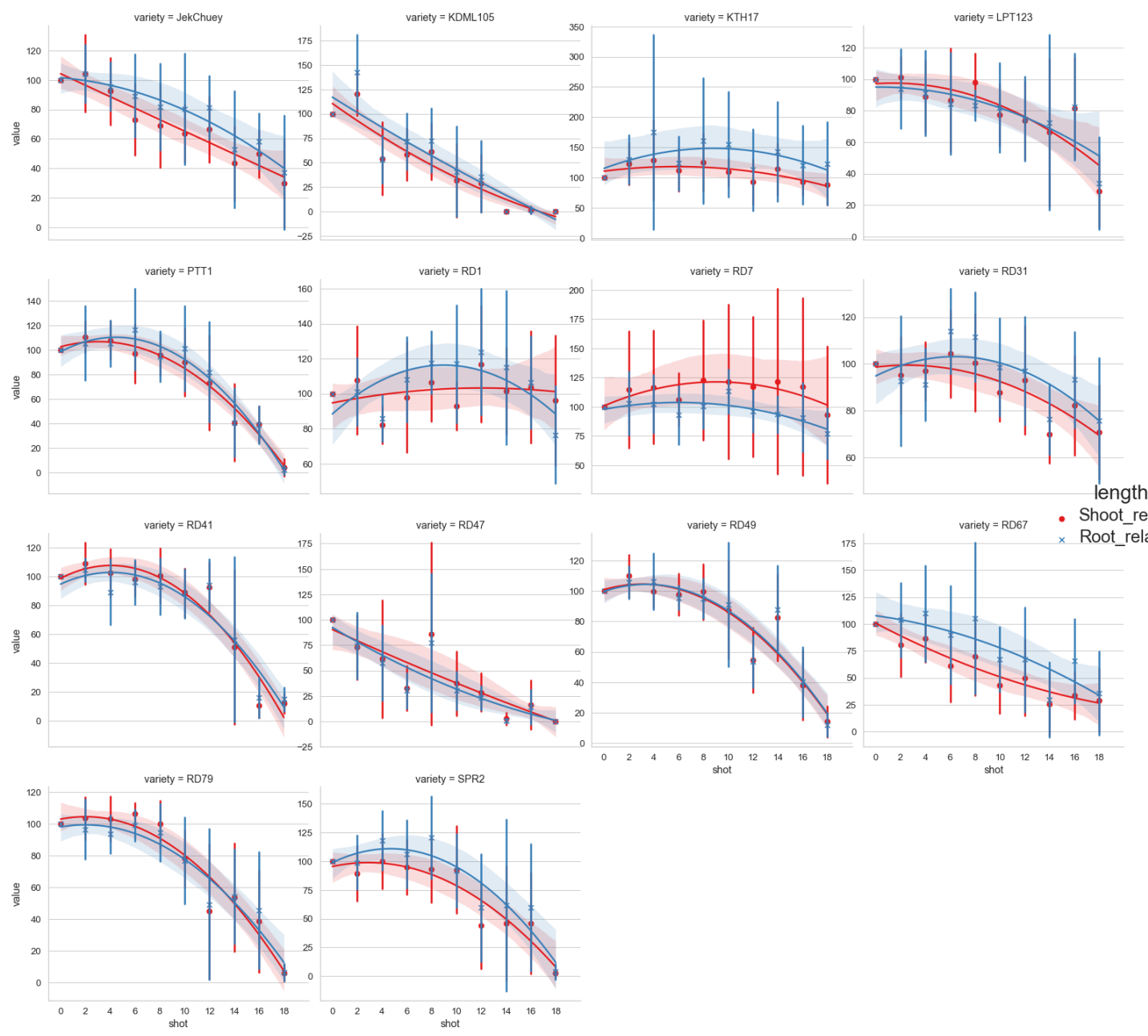

Figure 2 Growth percentages of seedlings roots and shoots of 14 Thai rice varieties at 10 days after plasma focus irradiation. Error bars represent standard deviations. 


\section{Conclusions}

Sensitivity of rice seeds to plasma focus irradiation varied among different cultivars. The responses of 14 Thai rice varieties to plasma focus were assessed via 2 characteristics: relative germination and relative growth. Using up to 18 plasma shots, the percentages of germination and growth rate of some rice varieties were decreased by less than $50 \%$. The $\mathrm{LD}_{50}$ and $\mathrm{GR}_{50}$ showed that Jek Chuey, KDML105, LPT123, PTT1, RD41, RD47, RD49, RD67, RD79, and SPR2 were more sensitive to plasma focus than KTH17, RD1, RD7, and RD31. The plasma focus effects on seed germination and seedling growth in vegetative phases of rice will be investigated further in the near future.

\section{Acknowledgements}

The authors thank the Rice Department, Ministry of Agriculture and Cooperatives, for providing the rice seeds for the experiment.

\section{References}

[1] RA Behbahani and C Xiao. Common features of particle beams and x-rays generated in a low energy dense plasma focus device. Phys. Plasmas 2015; 22, 020708.

[2] P Knoblauch, V Raspa, FD Lorenzo, A Clausse and C Moreno. Hard x-ray dosimetry of a plasma focus suitable for industrial radiography. Radiat. Phys. Chem. 2018; 145, 39-42.

[3] E Skladnik-Sadowska, D Zaloga, MJ Sadowski, R Kwiatkowski1, K Malinowski, R Miklaszewski, M Paduch, W Surala, E Zielinska and K Tomaszewski. Research on soft x-rays in high-current plasma-focus discharges and estimation of plasma electron temperature. Plasma Phys. Control. Fusion 2016; 58, 095003.

[4] A Tamman, M Nisoa, B Paosawatyanyong, D Boonyawan, N Poolyarat and T Onjun. Modelling and electrical characteristics of the Thailand plasma. Walailak J. Sci. Tech. 2018; 15, 471-80.

[5] S Lee. Plasma focus radiative model: Review of the Lee model code. J. Fusion Energ. 2014; 33, 319-35.

[6] J Jiang, Y Lu, J Li, L Li, X He, H Shao and Y Dong. Effect of seed treatment by cold plasma on the resistance of tomato to Ralstonia solanacearum (bacterial wilt). PLoS One 2014; 9, e97753.

[7] S Kitazaki, T Sarinont, K Koga, N Hayashi and M Shiratani. Plasma induced long-term growth enhancement of Raphanus sativus L. using combination atmospheric air dielectric barrier discharge plasmas. Curr. Appl. Phys. 2014; 14, S149-S153.

[8] A Nikiforov, X Deng, Q Xiong, U Cvelbar, N DeGeyter, R Morent and C Leys. Non-thermal plasma technology for the development of antimicrobial surfaces: A review. J. Phys. D Appl. Phys. 2016; 49, 204002.

[9] C Shao, D Wang, X Tang, L Zhao and Y Li. Stimulating effects of magnetized arc plasma of different intensities on the germination of old spinach seeds. Math. Comput. Model. 2013; 58, 8148.

[10] H Yamaguchi, Y Hase, A Tanaka, N Shikazono, K Degi, A Shimizu and T Morishita. Mutagenic effects of ion beam irradiation on rice. Breed. Sci. 2009; 59, 169-77.

[11] X Xu, B Liu, L Zhang and Y Wu. Mutagenic effects of heavy ion irradiation on rice seeds. Nucl. Instrum. Methods Phys. Res. B 2012; 290, 19-25.

[12] Akshatha and KR Chandrashekar. Effect of gamma irradiation on germination growth and biochemical parameters of Pterocarpus santalinus, an endangered species of Eastern Ghats. Eur. J. Exp. Biol. 2013; 3, 266-70.

[13] N Jaipo, M Kosiwikul, N Panpuang and K Prakrajang. Low dose gamma radiation effects on seed germination and seedling growth of cucumber and okra. J. Phys. Conf. Ser. 2019; 1380, 012106.

[14] JS Kim, MH Baek, L Young-Keun, HY Lee and JC Yoo. Effect of low dose gamma radiation to enhance germination rate in bottle gourd and pumpkin seeds. Korean J. Environ. Agric. 2002; 21, 202-7. 
[15] P Orpong, V Khamvarn, K Boonsirichai, V Puripunyavanich and S Insawat. Determination of electrom-beam radiation doses applicable for mutation breeding of rice. In: Proceedings of the URU International Conference on Science Technology, Thailand. 2018, p. 40-5.

[16] TA Wiendl, FW Wiendl, PB Arthur, SSH Franco, JG Franco, V Arthur and PB Arthur. Effects of gamma radiation in tomato seeds. In: Proceedings of the International Nuclear Atlantic Conference, Brazil. 2013.

[17] MS Abdel-Hady, EM Okasha, SSA Soliman and M Talaat. Effect of gamma radiation and gibberellic acid on germination and alkaloid production in Atropa belladonna L. Aust. J. Basic Appl. Sci. 2008; 2, 401-5.

[18] AM Kuzin, ME Vagabova and AF Revin. Molecular mechanisms of stimulating action of an ionizing radiation on seeds. 2. Activation of protein and high-molecular RNA synthesis (in Russian). Radiobiologiia 1976; 16, 259-61.

[19] B Adhikari, M Adhikari and G Park. The effects of plasma on plant growth, development, and sustainability. Appl. Sci. 2020; 10, 6045.

[20] V MildaZiene, V Aleknaviciute, R Zukiene, G Pauzaite, Z Nauciene, I Filatova, V Lyushkevich, P Haimi, I Tamosiune and D Baniulis. Treatment of common sunflower (Helianthus annus L.) seeds with radio-frequency electromagnetic field and cold plasma induces changes in seed phytohormone balance, seedling development and leaf protein expression. Sci. Rep. 2019; 9, 6437.

[21] F Yasmine, MA Ullah, F Ahmad, MA Rahman and AR Harun. Effects of chronic gamma irradiation on three rice varities. Jurnal Sains Nuklear Malaysia 2019; 31, 1-10.

[22] R Sasikala and R Kalaiyarasi. Sensitivity of rice varieties to gamma irradiation. Electron. J. Plant Breed. 2010; 1, 885-9.

[23] AA Rezk, JM Al-Khayri, AM Al-Bahrany, HS El-Beltagi and HI Mohamed. X-ray irradiation changes germination and biochemical analysis of two genotypes of okra (Hibiscus esculentus L.). $J$. Radiat. Res. Appl. Sci. 2019; 12, 393-402.

[24] D Cui, Y Yin, J Wang, Z Wang, H Ding, R Ma and Z Jiao. Research on the physio-biochemical mechanism of non-thermal plasma-regulated seed germination and early seedling development in Arabidopsis. Front. Plant Sci. 2019; 10, 1322.

[25] L Sivachandiran and A Khacef. Enhanced seed germination and plant growth by atmospheric pressure cold air plasma: combined effect of seed and water treatment. RSC Adv. 2017; 7, 1822-32.

[26] R Zhou, J Li, R Zhou, X Zhang and S Yang. Atmospheric-pressure plasma treated water for seed germination and seedling growth of mung bean and its sterilization effect on mung bean sprouts. Innov. Food Sci. Emerg. Technol. 2019; 53, 36-44.

[27] L Ling, L Jiangang, S Minchong, Z Chunlei and D Yuanhua. Cold plasma treatment enhances oilseed rape seed germination under drought stress. Sci. Rep. 2015; 5, 13033.

[28] B Adhikari, M Adhikari, B Ghimire, G Park and EH Choi. Cold atmospheric plasma-activated water irrigation induces defense hormone and gene expression in tomato seedlings. Sci. Rep. 2019; 9, 16080 .

[29] T Stolárik, M Henselová, M Martinka, O Novák, A Zahoranová and M Cernák. Effect of lowtemperature plasma on the structure of seeds, growth and metabolism of endogenous phytohormones in pea (Pisum sativum L.). Plasma Chem. Plasma Process. 2015; 35, 659-76. 